\title{
Analysing the Severity of Coronavirus Infection in Air Pollution: Evidence-Based Study From Saudi Arabia
}

Abdulnoor Ali Jazem Ghanim ( $\sigma$ aaghanim@nu.edu.sa )

Najran University Faculty of Engineering https://orcid.org/0000-0002-4020-9402

Research Article

Keywords: SARS-CoV-2, air pollution, COVID-19, concentration, atmosphere, health

Posted Date: April 5th, 2021

DOI: https://doi.org/10.21203/rs.3.rs-305670/v1

License: @) (i) This work is licensed under a Creative Commons Attribution 4.0 International License. Read Full License 


\section{Abstract}

COVID-19 has been considered as one of the major global pandemic which has caused different health problems by affecting the majority of the population throughout the world. Several studies have evolved the concerns of air pollution being considered as a major risk factor causing respiratory infection that are carried out by microorganisms which further affects the immunity system of the body. The present study involves the relationship between the air pollutants and COVID-19 total infection along with estimation of death rates in the several regions of Saudi Arabia. The major goal of this study comprises the analysis of the relationship between air pollutants concentration such as (PM10, NO2, CO, SO2 and 03) and COVID-19 wide outbreak, concerning the transmission, number of patients, critical cases and death rates. The results show that the estimation of COVID-19 cases were highest in number recorded in the most polluted regions, the mortality rate and critical cases were also more distinct in these regions more than other regions in Saudi Arabia. The finding of this study shows a positive correlation between mean PM 10, NO2, CO and SO2 pollutants. The results represent the significant relationship between air pollution resulting from high concentration of NO2 and COVID-19 infection and deaths. Null hypothesis of the relation between other pollutants and COVID-19 infection couldn't be rejected. The study also indicates significant correlation between mean NO2 and CO and total number of critical cases, and negative correlations were obtained between Mean 03 and total number of cases, total deaths and critical case per cumulative days.

\section{Introduction}

Recently, a highly infectious virus named as SARS CoV-2 virus coronavirus has arised causing breakdown of COVID-19 pandemic causing health problems among the individuals across the globe. The COVID-19 on going pandemic has propagated rapidly and has sparked a universal health crisis This outbreak of COVID-19 has originated and transmitted rapidly leading towards the impact of universal health crisis (Adly et al. 2020). The transmission of COVID-19 has evolved through the infections from droplets by human breathing and through the direct contact with the affected individuals that has been already studied during July, 2020. The pandemic of COVID-19 has resulted in the occurrence of almost $14,747,822$ cases across the world that further involves 610,791 death rates and $8,803,885$ recovery rates (WHO 2020). It has been found that the current estimation of infected cases involves estimation of 5,333,146 cases among which $5,273,445$ cases have been found to have mild conditions with $99 \%$ rates and the remaining 59,701 cases have been found to have critical conditions with $1 \%$ rate estimation (WHO 2020 ). Concerning the cases in Saudi Arabia, 250,920 confirmed cases of COVID-19 have been recorded until October, 2020 (Adly et al. 2020 ). Total number of confirmed cases has been obtained to be 338,539 and the total number of deaths have been determined as 4996 along with a fatality rate of $1.5 \%$. Saudi Arabia has been ranked at second position in the affected regions of COVID-19 cases concerning the Eastern Mediterranean region majorly involving the two most sacred religious places for Muslims i.e., Mecca and Medina. Hence, it is necessary to know regarding the scenario in case numbers within the next 4-6 months, mainly during the Hajj pilgrimage season.

Novel coronavirus is considered as an explosive outbreak resulting in human mortality rate at rapid scale (Mizumoto et al. 2020). COVID-19 has symptoms of respiratory infections resulting in severe disease among certain groups of people, mainly involving the older population having some health related problems like diabetes, cardiovascular disease, etc. (Adler. 2020). The research is still ongoing concerning its epidemiology. This disease has found to be exponentially increasing at a higher rate. The emergence of coronavirus was found in 2019 in the city of Wuhan who experienced the first outbreak in China affecting almost seventy thousand individuals and death of more than eighteen hundred people within the prior 50 days of the pandemic. The novel coronavirus was found to affect 120,000 people resulting in mortality of $2.9 \%$ population among 109 countries and the figures are still counting. Hence, this has revealed that the transmission rate of SARS-CoV-2 is much higher due to the occurrence of genetic combination that results in enhancing its transmission ability.

The virus has been proved to be the novel coronavirus by the sequence based analysis done by isolating the sequences from the infected patients. Some of the research studies revealed that some population has adhered to this infection with intake of seafood while those individuals are also present who are infected without the consumption of any seafood. These observations proved the spreading capability of the virus among human beings which almost affected the whole world at a very high rate. Hence, the severity of the disease has been considered to be high. The virus has been transmitted at a higher rate because of the close contact of one person with another infected person that may be exposed widely due to sneezing, coughing, respiratory droplets and aerosols. These aerosols have the capability of penetrating into the human body, mainly affecting the lungs by inhaling through nose and mouth (Phan et al. 2020; Riou \& Althaus. 2020; Parry. 2020; Li et al. 2020).

The impact of air pollutants among the individuals have resulted in the cause of respiratory diseases and cardiovascular diseases leading to mortality among the population. The study analysis by WHO has revealed that the healthy life of individuals are deteriorated by exposure towards particulate matter for longer duration (Ezzati et al. 2002). The major air pollutants being responsible affecting human health include $\mathrm{NO}_{2}, \mathrm{CO}$ and $\mathrm{O}_{3}$.

The impact of $\mathrm{NO}_{2}$ consists of a complex mixture of different pollutants that are prevalent in the air concerned with the outdoor environment. The exposure towards $\mathrm{NO}_{2}$ is also found indoor occurring due to the unvented combustion appliances. Most of the urban population are 
affected by the exposure of $\mathrm{NO}_{2}$ which is prevalent in the atmosphere through motor vehicles which has been known as strong indicators for the emission of vehicles. It has been considered as one of the precursors for many harmful secondary air pollutants involving nitric acid, nitrate part of secondary inorganic aerosols and photo oxidants involving ozone. It causes occurrence of photochemical reactions in the environment and further leads to generation of secondary air pollutants affecting the population. The exposure of $\mathrm{NO}_{2}$ affects the lungs along with mild airway inflammation occurrence in humans. Bronchial reactivity has been found to increase rapidly due to the exposure towards $\mathrm{NO}_{2}$. The hospital admissions showed cases of respiratory diseases due to increasing levels of $\mathrm{NO}_{2}$ in the environment. Also, cardiovascular disease occurrences have been observed among most of the population.

Carbon monoxide (CO) are another major air pollutant that are generated by motor vehicles and industries in the form of outdoor pollution and are emitted from unflued gas heaters, wood-burning heaters, and contained in cigarette smoke in the form of indoor pollution. It has major effects on the health of humans as it decreases the oxygen level reaching out the body organs such as the heart and brain. An extreme increase in the $\mathrm{CO}$ level tends to cause death among the individuals. Symptoms like headaches, dizziness, disorientation, nausea and fatigue are the major symptoms among people who are affected from this air pollutant. It causes coronary heart diseases with chest pain among the affected population. If the concentration of $\mathrm{CO}$ increases in the environment, impaired vision along with symptoms of dizziness and confusion tends to occur. Adverse health impact among unborn babies when exposed towards high concentration of CO has been observed among the population.

Dust is the major source of air pollutant in Saudi Arabia that tends to cause air pollution. The human induced air pollution is prevalent in Saudi Arabia and therefore to combat this issue, lead free gasolines are coveted and sulfur level is tended to decrease by $95 \%$ in Saudi Arabian regions. The level of air pollutants are increasing from the fuel combustion by emissions from different sectors involving transportation, power generation, desalination of seawater and industrial factories. These are responsible for emitting pollutant concentrations and emissions at higher levels in the environment.

Many studies have shown that the major air pollutants causing adverse health effects in Saudi Arabia include particulate matter (PMs), carbon monoxide (CO), carbon dioxide $\left(\mathrm{CO}_{2}\right)$, sulfur dioxide $\left(\mathrm{SO}_{2}\right)$, nitrogen dioxide $\left(\mathrm{NO}_{2}\right)$ and heavy metals (Al Mulla et al. 2015; Argyropoulos et al. 2016; Farahat. 2016; Omidvarborna et al. 2018; Saraga et al. 2017). It has been found that incomplete burning of the Arabian incense generates the emission of CO, PM10, PM2.5, black carbon and polycyclic aromatic hydrocarbons (PAHs), causing adverse health impact on the population who are prone towards exposure of these emissions (Du et al. 2018). These air pollutants have tended to cause ischemic heart diseases (IHD), chronic obstructive pulmonary diseases (COPD) and lung cancer among population of Saudi Arabia (Amoatey et al. 2018; Tageldin et al. 2012; Thurston et al. 2016).

On analysing the health variabilities, it has been found that most of the individuals suffering from COVID-19 infection were already prone to air pollution as the regions of Saudi Arabia are prone to high pollution rates. The air pollutants emerging from the vehicles and industries in Saudi Arabia has been the major source of pollution. Covid-19 affects the respiratory system of the human body and individuals who are already prone to some respiratory disease tend to get affected from the pandemic.

Several Italian studies revealed air pollution being a risk factor during COVID-19. A correlation with higher level of PM has major impact on the human health among the areas of Northern Italy (Domingo et al. 2020; Martelletti et al. 2020; Sciomer et al. 2020; Zoran et al. 2020). Another study analyzed the involvement of PM10 emerging from an industrial site of Bergamo Province which has been considered as the epicentre of Italian COVID-19 epidemic (Setti et al. 2020). The results from these sites have revealed that SARS-CoV-2 has shown its presence in the PM during the atmospheric stability and at higher concentrations of $\mathrm{PM}_{10}$ representing as the first experimental proof for COVID-19 case found on PM (Distante et al. 2020). It has also been found that populations dwelling in regions with high concentrations of air pollutants are responsible for developing chronic respiratory infections and are proven to be more sensitive to any infectious agent. Also, exposure towards air pollution for longer duration results in chronic inflammatory stimulus among young and healthy individuals (Conticini et al. 2020). Another major study revealed a correlation between the COVID-19 infection and air pollution that has a major impact on increasing the infection and mortality rate (Frontera et al. 2020).

The lockdown in COVID-19 has assessed the human activities majorly involving vehicle use and public transportation along with involvement of industrial processes (Pata. 2020; Gautam. 2020; Bashir et al. 2020; Shehzad et al. 2020). Many studies have shown the relevance of air pollution and COVID-19. Transmission of COVID-19 has been found prevalent through airborne bio aerosol droplets along with various parameters of urban air pollution (Bashir et al. 2020; Fareed et al. 2020). Past exposure of air pollution has increased the cases of COVID-19. Air pollution shows capability of transporting these viruses. The evidence of air pollution involves the mortality rate from the cases of COVID-19 with past exposure towards air pollutants. Emissions from transportation and energy evolves from increased pollution concerning local regions within cities of Saudi Arabia. The pollutants concerned with industries producing increased levels of pollution among the Saudi Arabian industries like oil, natural gas, cement, and chemical industries. The industrial pollution tends to increase the mortality rate and occurrence of respiratory and cardiovascular diseases (Brauer. 2010; Perez et al. 2020). Emissions from the GCC and Middle East fuel brings alterations in the global atmosphere that have tended to increase. The pollution from airplanes and ships evolves emissions in this region. CO2 emissions evolved from 
fossil fuel combustion and industries increased the pollution rate. Governance systems and ecological attributes make populations in the Middle East particularly and have a major impact on the natural climatic conditions (Sowers. 2011).

The present study aimed for analyzing the relationship between ambient air pollutants and COVID-19 total infection and death rate in Saudi Arabia regions. The collected data and its analysis evolved the clarity on the fact showing correlation of air pollution in various Saudi Arabian regions with COVID-19 cases involving mortality rate and critical cases. The analysis of impact of COVID-19 wide outbreak concerning transmission, number of patients, critical cases and number of deaths was significantly proved. The impact of past exposure towards the air pollutants has affected the COVID-19 cases and it has been determined with facts and figures in the present study. Hence, the present study has been considered as an helpful approach for understanding the importance of reduction of the air pollutant concentration in the atmosphere for leading a healthier life.

\section{Methods}

\section{Study area and data}

This study included 10 regions out of 13 regions (Makkah Al Mukarramah, Ar Riyad, Eastern Region, Al Madinah Al Munawwarah, Aseer, Al Qaseem, Jazan, Hail, Tabuk, Al Jouf, Al Baha, Najran, Northern Region) in the geographic regions of Saudi Arabia with $45.0792^{\circ}$ east longitude and $23.885^{\circ}$ north latitude. Fig. 1 shows a map of Saudi Arabia outlining its 13 administrative regions. According to the database collected from the website of the General authority of Meteorology and Environment Protection (GAMEP) (https://ncm.gov.sa/Ar/Environment/AirQuality/Pages/AQ-Reports.aspx?folderlD=351e1157-509d-46d1-8118-bd78d008e33d) , air pollutant data including $\mathrm{CO}, \mathrm{SO}_{2}, \mathrm{NO}_{2}, \mathrm{O}_{3}$, and PM10 was identified. Data on Covid-19 cases was extracted from Saudi Ministry of Health official website (https://covid19.moh.gov.sa). 194255 COVID-19 confirmed cases have been identified in the 13 regions of Saudi Arabia as of June $30,2020$. Our studied regions covered $70 \%$ of confirmed cases. We focused our analysis on these 10 regions of Saudi Arabia because of the limitation of the meteorological data and the air pollution data we have obtained. Air pollutant data were only available for 10 regions out of 13 regions of Saudi Arabia, but data on Covid-19 cases were available for all regions at the time of writing.

\section{Statistical analysis}

Statistical analysis was done using SPSS version 23. A descriptive analysis was executed for all the data. The extracted data was analysed using Spearman Correlations depicting correlation between mean PM 10, NO $2, \mathrm{CO}, \mathrm{SO}_{2}$ and $\mathrm{O}_{3}$ registered in May 2020 and COVID-19 cases in

terms of total number, Deaths and critical cases per cumulative days. All analyses in this study were conducted using the Spearman Correlations coefficients between mean values of $\mathrm{PM} 10, \mathrm{NO}_{2}, \mathrm{CO}, \mathrm{SO} 2$ and 03 . The statistical tests were two-sided, and $\mathrm{P}$ values of less than 0.05 was considered statistically significant.

The statistical analysis of the study shows a positive correlation between mean $\mathrm{PM} 10, \mathrm{NO}_{2}, \mathrm{CO}$ and $\mathrm{SO}_{2}$ pollutants. The results represent the significant relationship between air pollution resulting from high concentration of $\mathrm{NO}_{2}$ and COVID-19 infection and deaths. Null hypothesis of the relation between other pollutants and COVID-19 infection couldn't be rejected. The study also indicates significant correlation between mean $\mathrm{NO}_{2}$ and $\mathrm{CO}$ and total number of critical cases.

\section{Findings and Discussion}

The present study aims towards analyzing the impact of COVID-19 wide outbreak concerning transmission, number of patients, critical cases and number of deaths along with analyzing the relationship between air pollutants concentration $\left(\mathrm{PM}_{10}, \mathrm{NO}_{2}, \mathrm{CO}_{3} \mathrm{SO}_{2}\right.$ and $\left.\mathrm{O}_{3}\right)$. Also, the link between air pollution in various Saudi Arabian regions and COVID-19 cases, mortality rate and critical cases has been represented in the given study for showing the efficacy of study that helps in representing correlation between air pollution and cases of COVID-19. A dataset concerning the air quality was obtained from the database of the General authority of Meteorology and Environment Protection (GAMEP) including CO, $\mathrm{SO}_{2}, \mathrm{NO}_{2}, \mathrm{O}_{3}$, and PM10 so that the aim of the study is fulfilled. Saudi Ministry of Health official site about COVID-19 was used for date extraction. The data involves the 13 regions of Saudi Arabia and consist of COVID-19 cases Dated June, 30, 2020. The data involved the measurement of total number of cases of COVID-19 in particular regions of Saudi Arabia along with evaluation of mean value of air pollutants such as $\mathrm{PM} 10, \mathrm{NO}_{2}, \mathrm{CO}, \mathrm{SO}_{2}$ and $\mathrm{O}_{3}$ registered in particular region of Saudi Arabia during May, 2020 one month before the start of the wider transmission of the COVID-19 epidemic in the Kingdom and the highest death rate in the country. Hence, the air pollution data of Saudi Arabia during COVID-19 helps in finding out the link between air pollution in various Saudi Arabian regions and COVID-19 cases, mortality rate and critical cases. Some of the data has been found missing in the dataset. The below Table 1 is the analysis data of air pollution of Saudi Arabian regions with air pollutant concentration and COVID-19 cases. . Air pollution data for Al Baha, Najran and Northern Region were unavailable at the time of writing. 
Table 1 Distribution of Covid-19 cases on June 30,2020 (total number of cases, Deaths, critical cases) as per each Saudi Arabia region and the mean value of PM 10, NO2, CO,SO2 and 03 registered in each region during May 2020.

\begin{tabular}{|c|c|c|c|c|c|c|c|c|}
\hline $\begin{array}{l}\text { Saudi Arabia } \\
\text { Regions }\end{array}$ & $\begin{array}{l}\text { Total number } \\
\text { of cases } \\
\text { (n) }\end{array}$ & $\begin{array}{l}\text { Deaths } \\
\text { (n) }\end{array}$ & $\begin{array}{l}\text { Critical } \\
\text { cases } \\
\text { (n) }\end{array}$ & $\begin{array}{l}\text { Mean PM10 in } \\
\text { May, } 2020 \\
\left(\mu \mathrm{g} / \mathrm{m}^{3}\right)\end{array}$ & $\begin{array}{l}\text { Mean } \mathrm{NO}_{2} \text { in } \\
\text { May, } 2020 \\
(\mathrm{ppb})\end{array}$ & $\begin{array}{l}\text { Mean CO in } \\
\text { May, } 2020 \\
(\mathrm{ppm})\end{array}$ & $\begin{array}{l}\text { Mean } \mathrm{SO}_{2} \text { in } \\
\text { May, } 2020 \\
(\mathrm{ppb})\end{array}$ & $\begin{array}{l}\text { Mean } \mathrm{O}_{3} \text { in } \\
\text { May, } 2020 \\
(\mathrm{ppb})\end{array}$ \\
\hline $\begin{array}{l}\text { Makkah Al } \\
\text { Mukarramah }\end{array}$ & 57548 & 954 & 482 & 101.00 & 12.76 & 0.74 & 6.24 & 28.97 \\
\hline Ar Riyad & 52932 & 383 & 512 & 97.48 & 13.07 & 1.18 & 2.63 & 17.85 \\
\hline $\begin{array}{l}\text { Eastern } \\
\text { Region }\end{array}$ & 48274 & 157 & 815 & 33.93 & 10.99 & 1.67 & 4.02 & 19.55 \\
\hline Al Madinah & 15106 & 98 & 82 & 97.09 & 11.15 & 0.75 & 3.35 & 20.87 \\
\hline Aseer & 7936 & 15 & 194 & 56.00 & 3.24 & 0.54 & 2.86 & 26.96 \\
\hline Al Qaseem & 3812 & 20 & 82 & 107.55 & 2.77 & 0.73 & 2.16 & 31.25 \\
\hline Jazan & 2448 & 30 & 23 & 21.40 & 5.60 & 1.01 & 4.92 & 8.19 \\
\hline Hail & 1619 & 3 & 37 & 107.62 & 4.62 & 0.55 & 2.52 & 41.42 \\
\hline Tabuk & 1555 & 17 & 5 & 79.38 & 5.02 & 0.68 & 3.38 & 39.46 \\
\hline Al Jouf & 248 & 2 & 2 & 27.64 & 1.99 & 0.68 & 7.61 & 37.75 \\
\hline Al Baha & 684 & 6 & 7 & NA & NA & NA & NA & NA \\
\hline Najran & 1662 & 1 & 33 & NA & NA & NA & NA & NA \\
\hline $\begin{array}{l}\text { Northern } \\
\text { Region }\end{array}$ & 431 & 15 & 2 & NA & NA & NA & NA & NA \\
\hline
\end{tabular}

Statistical analysis was done using SPSS version 23. A descriptive analysis was executed for all the data. The extracted data was analyzed using Spearman Correlations depicting correlation between mean PM 10, NO, $\mathrm{CO}_{2} \mathrm{SO}_{2}$ and $\mathrm{O}_{3}$ registered in May 2020 and COVID-19 cases in terms of total number, Deaths and critical cases per cumulative days. The below Table 2 represents the analysis of the data.

Table 2 Spearman Correlations coefficients between mean PM 10 ,NO2,CO,SO2 and 03 registered in May 2020 and COVID-19 cases in terms of total number, Deaths and critical cases per cumulative days (data updated to 30 Jun 2020). 


\begin{tabular}{|lll|}
\hline Correlations & $\begin{array}{l}\text { Pearson's coefficient } \\
(\mathbf{r} \text {-value })\end{array}$ & $\begin{array}{l}\text { Significance } \\
\text { (p-value) }\end{array}$ \\
\hline Mean PM 10 - Total number cases & 0.178 & 0.623 \\
\hline Mean PM 10 - Deaths & 0.334 & 0.345 \\
\hline Mean PM 10 Vs. Critical cases per cumulative days & -0.046 & 0.8995 \\
\hline Mean NO2 - Total number cases & & \\
\hline Mean NO2 - Deaths & 0.885 & 0.001 \\
\hline Mean NO2 Vs. Critical cases per cumulative days & 0.713 & 0.021 \\
\hline Mean CO - Total number cases & & 0.0184 \\
\hline Mean CO - Deaths & 0.607 & 0.063 \\
\hline Mean CO Vs. Critical cases per cumulative days & 0.7387 & 0.709 \\
\hline & & 0.0073 \\
\hline Mean SO2 - Total number cases & 0.098 & 0.136 \\
\hline Mean SO2 - Deaths & 0.327 & 0.290 \\
\hline Mean SO2 Vs. Critical cases per cumulative days & 0.0017 & 0.357 \\
\hline Mean O3 - Total number cases & -0.372 & 0.996 \\
\hline Mean O3 - Deaths & -0.138 & \\
\hline Mean O3 Vs. Critical cases per cumulative days & -0.3798 & 0.290 \\
\hline
\end{tabular}

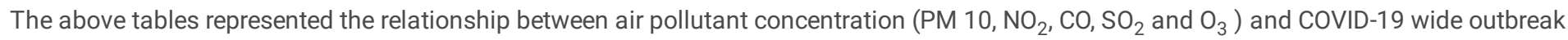
concerning the transmission, number of patients, critical cases and number of deaths. The study correlation was conducted to show the link between air pollution in various Saudi Arabian regions and COVID-19 cases, mortality rate and critical cases.

Positive correlations were obtained among the total number of cases and Mean PM 10, $\mathrm{NO}_{2}, \mathrm{CO}_{1} \mathrm{SO}_{2}$ and $\mathrm{O}_{3}$ (showing r-value $=0.178$, $0.885,0.607$ and 0.098 ). But, the correlation was only significant with $\mathrm{NO}_{2}$ (showing p-value as 0.001 ). However, appreciable correlation was obtained between mean CO and total number cases of COVID-19 in Saudi Arabia. Positive correlations was obtained between total number of deaths and mean $\mathrm{PM} 10, \mathrm{NO}_{2}, \mathrm{CO}$ and $\mathrm{SO}_{2}$ (showing r-value as $0.334,0.713,0.136$ and 0.327 ), but the correlation was only found significant with $\mathrm{NO}_{2}$ (showing p-value to be 0.021 ). Positive correlations were obtained between total critical cases per cumulative days and Mean $\mathrm{NO} 2, \mathrm{CO}$ and SO2 (showing r-value as $0.722,0.739$ and 0.0017 ). The correlation was observed to show significance with $\mathrm{NO}_{2}$ and $\mathrm{CO}$ with $\mathrm{p}$-value as 0.0184 and 0.0073 . Negative correlations were obtained between $\mathrm{Mean}_{3}$ and total number of cases, total deaths and critical cases per cumulative days with $r$-value as $-0.372,-0.138$ and -0.379 . The correlation did not show any significance with all these relations with $p$-value greater than 0.1 .

The correlation of the mean concentration of CO during May 2020 with the number of critical cases for COVID-19 infection per cumulative days (patient data updated at 30 June 2020) was represented by scatter plotting in Fig. 2.

Fig. 2 shows the relation between CO and number of critical cases of COVID-19. Most of the critical cases of COVID-19 have been found in the Eastern Region of Saudi Arabia. Hail and Aseer have determined to have the least number of critical cases of COVID-19 among all the 13 regions selected for the study in Saudi Arabia. Ryadh has been determined to have more critical cases when compared with Makkah. Al Qaseem, Jazan, Hail, Tabuk, Al Jouf, Al Baha, Najran have been also determined to have less number of critical cases when compared to other regions selected in this study. 
Hence, the above results showed that the estimation of the highest number of COVID-19 cases were recorded among the polluted regions, the mortality rate and critical cases were also more distinct in these regions more than other regions in Saudi Arabia. The finding of this study

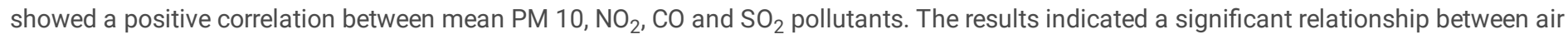
pollution resulting from high concentration of $\mathrm{NO}_{2}$ and COVID-19 infection and deaths. Null hypothesis of the relation between other pollutants and COVID-19 infection couldn't be rejected. The study also indicated significant correlation between mean $\mathrm{NO}_{2}$ and $\mathrm{CO}$ and total number of critical cases.

\section{Conclusion}

The present study involves the facts and figures concerning the impact of COVID-19 resulting in health related problems across the globe. The correlation of air pollution with the COVID-19 pandemic has been presented as the major respiratory diseases have been considered as the major outcome of the COVID-19. Covid-19 tends to affect the respiratory system in humans and the individuals who have experienced past exposure towards air pollutants are more prone to get affected from the COVID-19 infection. Hence, to show the relevancy, the present study evolves the relationship between ambient air pollutants and COVID-19 total infection and death rate in Saudi Arabian regions. The relationship between air pollutant concentration ( $\mathrm{PM} 10, \mathrm{NO}_{2}, \mathrm{CO}_{1} \mathrm{SO}_{2}$ and $\mathrm{O}_{3}$ ) and COVID-19 wide outbreak concerning the transmission, number of patients, critical cases and number of deaths has been analyzed in this study. The highest number of COVID-19 cases has been recorded in the most polluted regions and the mortality rate and critical cases has been found to be more distinct in these regions more than other regions in Saudi Arabia. Hence, a positive correlation between mean PM 10, NO2, CO and SO2 pollutants is obtained showing a significant relationship between air pollution resulting from high concentration of NO2 and COVID-19 infection and deaths.

\section{Declarations}

\section{Acknowledgement}

The authors would like to express their Gratitude to the ministry of education and the deanship of scientific research - Najran University Kingdom of Saudi Arabia for their financial and technical support.

\section{Authors Contribution}

The author confirms sole responsibility for the following: study conception and design, data collection, analysis and interpretation of results, and manuscript preparation.

\section{Funding}

This research was funded by the ministry of education and the deanship of scientific research - Najran University - Kingdom of Saudi Arabia

\section{Data availability}

The data that support the findings of this study are were extracted from Saudi Ministry of Health official website [https://covid19.moh.gov.sa]. and from the website of the General authority of Meteorology and Environment Protection (GAMEP) [

https://ncm.gov.sa/Ar/Environment/AirQuality/Pages/AQ-Reports.aspx?folderlD=351e1157-509d-46d1-8118-bd78d008e33d ]

Ethics approval and consent to participate Not applicable

Consent for publication Not applicable

Conflict of interest The authors declare that they have no known competing financial interests or personal relationships that could have appeared to influence the work reported in this paper.

\section{References}

1. Argyropoulos C, Abraham M, Hassan H, Ashraf A, Fthenou E, Sadoun E, Kakosimos K (2016) Modeling of PM10 and PM2. 5 building infiltration during a dust event in Doha, Qatar. In Proceedings of 2nd International Conference on Atmospheric Dust-DUST2016, Castellaneta Marina-Taranto, Italy. DOI: https://doi.org/10.14644/dust.2016.001

2. Adler S. E (2020). Why Coronaviruses hit older adults hardest. AARP. Retrieved from https://cdn.ymaws.com/www.servicecoordinator.org/resource/resmgr/images/misc_/coronavirus_2020/aarp_why_coronaviruses_hit_o.pdf . Accessed 26 December 2020 
3. Adly HM , AlJahdali I A, Garout MA, Khafagy AA, Saati, A. A, Saleh S. A (2020) Correlation of COVID-19 Pandemic with Healthcare System Response and Prevention Measures in Saudi Arabia. International Journal of Environmental Research and Public Health 17(18):6666. DOI:https://doi.org/10.3390/ijerph17186666

4. Al Mulla A, Fanous N, Seidenberg AB, Rees, VW (2015) Secondhand smoke emission levels in waterpipe cafes in Doha, Qatar. Tobacco control, 24(e3): e227-e231. DOI: http://dx.doi.org/10.1136/tobaccocontrol-2014-051717

5. Amoatey P, Omidvarborna, H, Baawain M (2018) The modeling and health risk assessment of PM2.5 from Tema Oil Refinery. Human and Ecological Risk Assessment: An International Journal 24(5):1181-1196. DOI: https://doi.org/10.1080/10807039.2017.1410427

6. Bashir M. F, Benghoul M, Numan U, Shakoor A, Komal B, Bashir M. A, Tan D (2020) Environmental pollution and CoVID-19 outbreak: insights from Germany. Air Quality, Atmosphere \& Health 13(11):1385-1394. DOI: https://doi.org/10.1007/s11869-020-00893

7. Conticini E, Frediani B, Caro D (2020) Can atmospheric pollution be considered a co-factor in extremely high level of SARS-CoV-2 lethality in Northern Italy?. Environmental pollution 261: 114465. DOI: https://doi.org/10.1016/j.envpol.2020.114465

8. Distante C, Piscitelli P, Miani A. (2020) Covid-19 outbreak progression in Italian regions: Approaching the peak by the end of March in northern Italy and first week of April in Southern Italy. International Journal of Environmental Research and Public Health 17(9):3025.

9. Domingo J , Marquès M, Rovira J (2020) Influence of airborne transmission of SARS-CoV-2 on COVID-19 pandemic. A review. Environmental research :109861. DOI: https://doi.org/10.1016/j.envres.2020.109861

10. Du W, Li X, Chen Y, Shen G (2018) Household air pollution and personal exposure to air pollutants in rural China-A review. Environmental pollution 237: 625-638. DOI: https://doi.org/10.1016/j.envpol.2018.02.054

11. Ezzati M, Lopez AD, Rodgers A, Vander Hoorn S, Murray CJ (2002) Comparative Risk Assessment Collaborating Group. Selected major risk factors and global and regional burden of disease. The Lancet 360(9343) : 1347-1360.

12. Fareed Z, Iqbal N, Shahzad F, Shah, SGM., Zulfiqar, B, Shahzad, K., ... \& Shahzad, U (2020) Co-variance nexus between COVID-19 mortality, humidity, and air quality index in Wuhan, China: New insights from partial and multiple wavelet coherence. Air Quality, Atmosphere, \& Health 13: 673-682 DOI: https://doi.org/10.1007/s11869-020-00847-1

13. Farahat A (2016) Air pollution in the Arabian Peninsula (Saudi Arabia, the United Arab Emirates, Kuwait, Qatar, Bahrain, and Oman): causes, effects, and aerosol categorization. Arabian Journal of Geosciences 9(3): 196. DOI: https://doi.org/10.1007/s12517-015-2203-y

14. Frontera JA, Sabadia, S, Lalchan R, Fang T, Flusty B, Millar-Vernetti $P, \ldots$ \& Morgan, N (2021) A prospective study of neurologic disorders in hospitalized COVID-19 patients in New York City. Neurology 96(4): e575-e586. DOI: https://doi.org/10.1212/WNL.0000000000010979

15. Gautam S (2020) COVID-19: air pollution remains low as people stay at home. Air Quality, Atmosphere, \& Health 13:853-857. DOI: https://doi.org/10.1007/s11869-020-00842-6

16. Li Q, Guan X,Wu P, Wang X, Zhou L, Tong Y, ... \& Xing X (2020) Early transmission dynamics in Wuhan, China, of novel coronavirus-infected pneumonia. New England Journal of Medicine. DOI: https://doi.org/10.1056/NEJMoa2001316

17. Martelletti L, Martelletti P (2020) Air pollution and the novel Covid-19 disease: a putative disease risk factor. SN Comprehensive Clinical Medicine 2(4): 383-387. DOI: https://doi.org/10.1007/s42399-020-00274-4

18. Mizumoto K, \& Chowell G (2020) Transmission potential of the novel coronavirus (COVID-19) onboard the Diamond Princess Cruises Ship. Infectious Disease Modelling 5: 264-270. DOI: https://doi.org/10.1016/j.idm.2020.02.003

19. Omidvarborna H, Baawain M, \& Al-Mamun A (2018) Ambient air quality and exposure assessment study of the Gulf Cooperation Council countries: A critical review. Science of the Total Environment 636: 437-448. DOI: https://doi.org/10.1016/j.scitotenv.2018.04.296

20. Parry J (2020) China coronavirus: cases surge as official admits human to human transmission. DOI: https://doi.org/10.1136/bmj.m236

21. Pata UK (2020) How is COVID-19 affecting environmental pollution in US cities? Evidence from asymmetric Fourier causality test. Air Quality, Atmosphere \& Health 13(10): 1149-1155. DOI: https://doi.org/10.1007/s11869-020-00877-9

22. Phan LT, Nguyen T. V, Luong QC, Nguyen TV, Nguyen HT, Le HQ, ... \& Pham QD (2020) Importation and human-to-human transmission of a novel coronavirus in Vietnam. New England Journal of Medicine 382(9): 872-874. DOI: https://doi.org/10.1056/NEJMc2001272

23. Riou J, Althaus CL (2020) Pattern of early human-to-human transmission of Wuhan 2019 novel coronavirus (2019-nCoV), December 2019 to January 2020. Eurosurveillance 25(4): 2000058. DOI: https://doi.org/10.2807/1560-7917.ES.2020.25.4.2000058

24. Saraga D, Maggos T, Sadoun E, Fthenou E, Hassan H, Tsiouri V, ... \& Kakosimos K (2017) Chemical characterization of indoor and outdoor particulate matter (PM2. 5, PM10) in Doha, Qatar. Aerosol and Air Quality Research 17(5):1156-1168. DOI: https://doi.org/10.4209/aaqr.2016.05.0198

25. Sciomer S, Moscucci F, Magrì D, Badagliacca R, Piccirillo G, Agostoni P (2020) SARS-CoV-2 spread in Northern Italy: what about the pollution role?. Environmental Monitoring and Assessment 192: 1-3. DOI: https://doi.org/10.1007/s10661-020-08317-y

26. Setti L, Passarini F, De Gennaro G, Barbieri P, Licen S, Perrone MG, ... \& Rizzo E (2020) Potential role of particulate matter in the spreading of COVID-19 in Northern Italy: first observational study based on initial epidemic diffusion. BMJ open, 10(9) : e039338. DOI:

http://dx.doi.org/10.1136/bmjopen-2020-039338

Page $8 / 10$ 
27. Shehzad K, Sarfraz, M, Shah, S GM. (2020) The impact of COVID-19 as a necessary evil on air pollution in India during the lockdown. Environmental Pollution, 266: 115080. DOI: https://doi.org/10.1016/j.envpol.2020.115080

28. Sowers J, Vengosh A, Weinthal, E (2011) Climate change, water resources, and the politics of adaptation in the Middle East and North Africa. Climatic Change 104(3-4): 599-627. DOI: https://doi.org/10.1007/s10584-010-9835-4

29. Tageldin MA, Nafti S, Khan, JA, Nejjari C, Beji M, Mahboub B, ... \& Rashid N (2012) Distribution of COPD-related symptoms in the Middle East and North Africa: results of the BREATHE study. Respiratory medicine 106: S25-S32. DOI: https://doi.org/10.1016/S0954-

6111(12)70012-4

30. Thurston GD, Burnett RT, Turner MC, Shi Y, Krewski D, Lall R, ... \& Pope III CA (2016) Ischemic heart disease mortality and long-term exposure to source-related components of US fine particle air pollution. Environmental health perspectives, 124(6): 785-794. DOI:

https://doi.org/10.1289/ehp.1509777

31. World Health Organization. (2020) Coronavirus disease 2019 (COVID-19): situation report, 82.

32. Zoran MA, Savastru RS, Savastru DM,Tautan MN (2020) Assessing the relationship between surface levels of PM2. 5 and PM10 particulate matter impact on COVID-19 in Milan, Italy. Science of The Total Environment 738: 139825. DOI: https://doi.org/10.1016/j.scitotenv.2020.139825

\section{Figures}

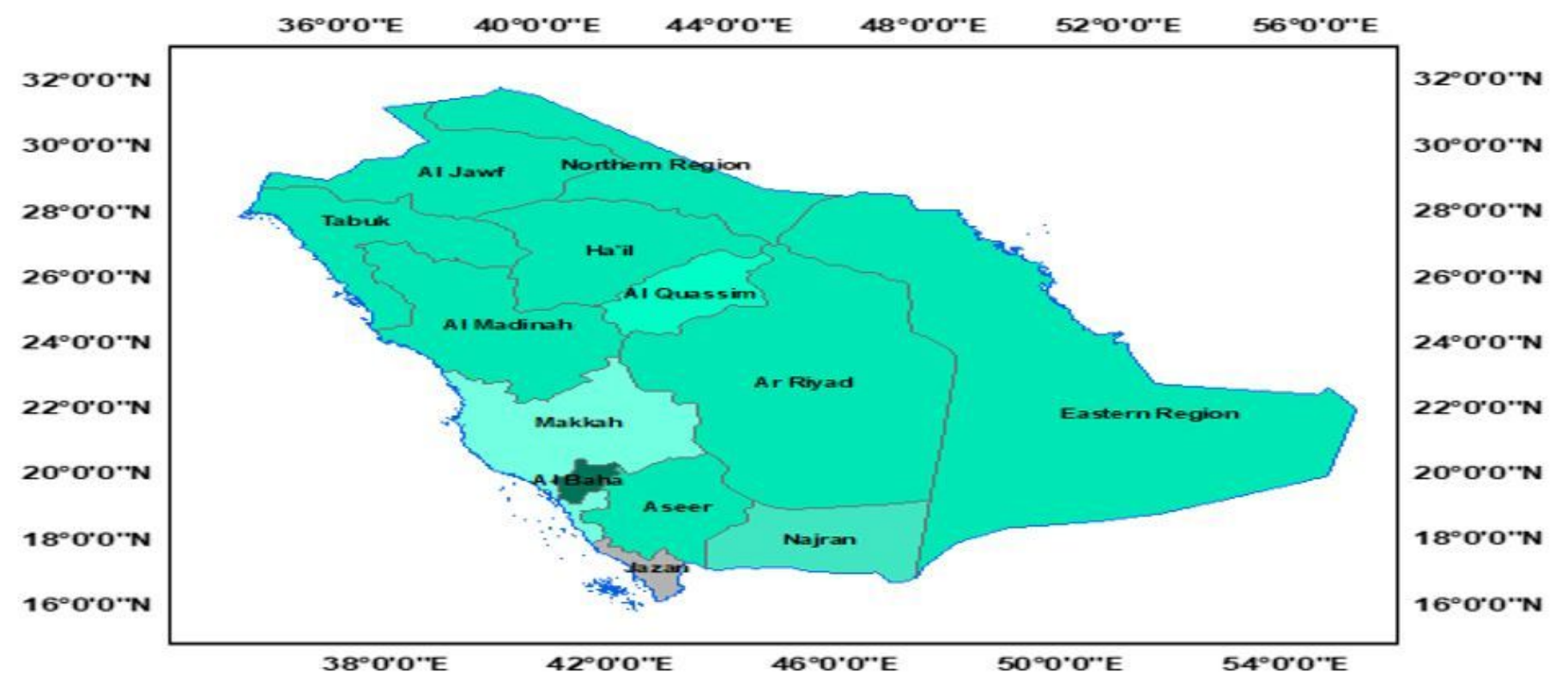

Figure 1

Map of Saudi Arabia regions showing its 13 administrative regions Note: The designations employed and the presentation of the material on this map do not imply the expression of any opinion whatsoever on the part of Research Square concerning the legal status of any country, territory, city or area or of its authorities, or concerning the delimitation of its frontiers or boundaries. This map has been provided by the authors. 


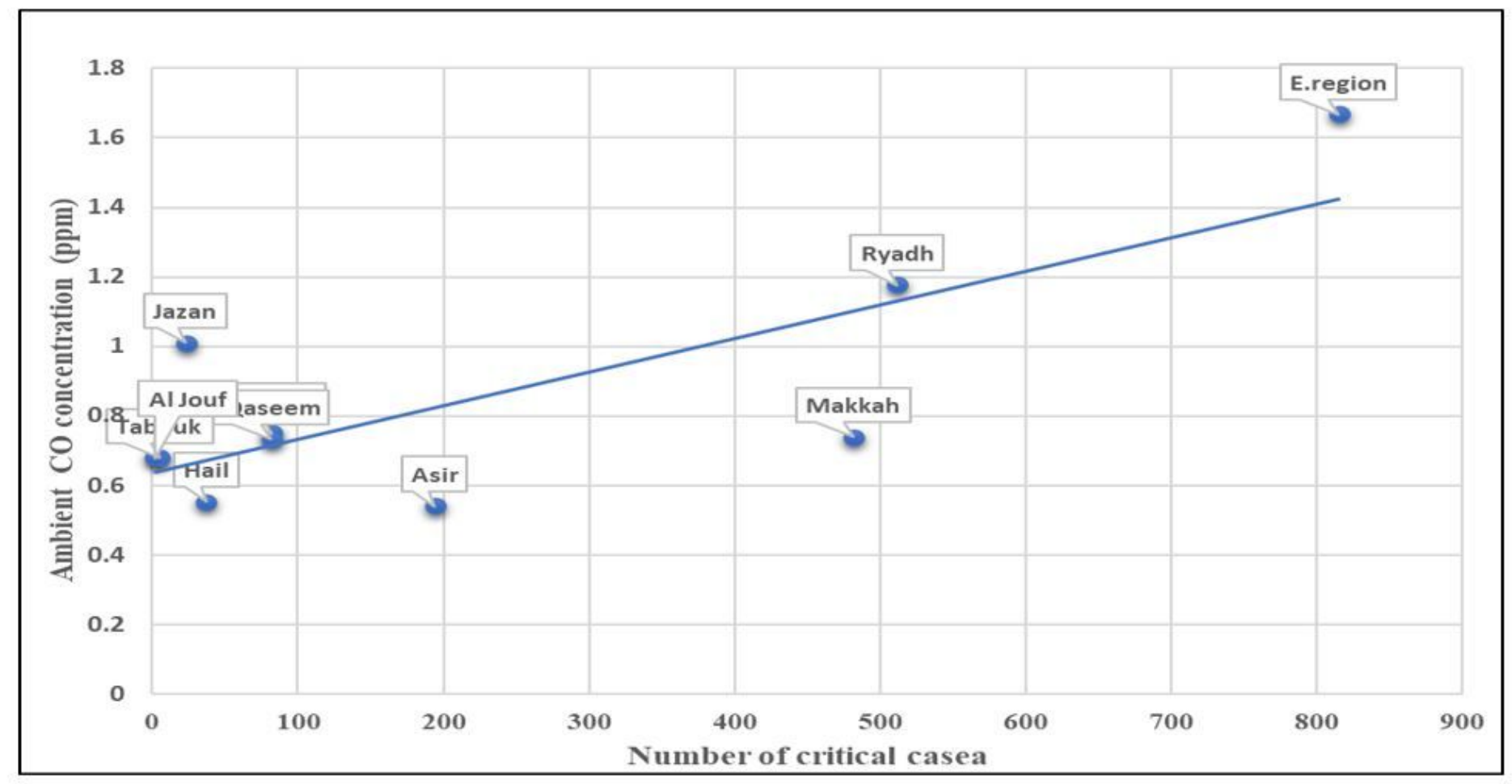

Figure 2

Scatter plot showing the correlation of the mean concentration of CO during May 2020 with the number of critical cases for COVID-19 infection per cumulative days (patient data updated at 30 June 2020). Regions presented the highest level of CO pollution during the month of May, 2020 are the ones presenting with more severe.

\section{Supplementary Files}

This is a list of supplementary files associated with this preprint. Click to download.

- GraphicalAbstract.jpg 